Available online:

http://journal.imla.or.id/index.php/arabi

IMLA

Arabi : Journal of Arabic Studies, 5 (2), 2020, 117-129

DOI: http://dx.doi.org/10.24865/ajas.v5i2.294

\title{
USING THE BLENDED LEARNING AS AN ALTERNATIVE MODEL OF ARABIC LANGUAGE LEARNING IN THE PANDEMIC ERA
}

\author{
Danial Hilmi, Nur lla Ifawati \\ Universitas Islam Negeri Maulana Malik Ibrahim Malang, Indonesia \\ E-mail : hilmi@pba.uin-malang.ac.id
}

\begin{abstract}
Arabic language learning in the modern era demands mastery of technology in all fields, especially during the Covid-19 pandemic which requires learning assistance. Therefore, the use of blended learning needs to be addressed in the Arabic teaching and learning process. The aim of this study was to describe the implementation of Arabic teaching through blended learning and using blended learning as an alternative model to Arabic language learning in the pandemic era. The study used mixed method that combines qualitative and quantitative approaches descriptively. The data were obtained from interviews, documentation and the results of a survey of the Arabic language learning process obtained from Arabic language teachers. The results showed that the implementation of Arabic language learning through blended learning using a platform that is considered effective according to the conditions of the teacher and students, and the use of blended learning is actually an alternative to implementing face-to-face learning to provide monitoring of language habits.
\end{abstract}

Keywords: blended Learning, Arabic, pandemic

\begin{abstract}
Abstrak
Pembelajaran bahasa Arab di era modern menuntut penguasaan teknologi di segala bidang terutama di masa pandemi Covid-19 yang membutuhkan pendampingan pembelajaran. Oleh karena itu, pemanfaatan blended learning perlu mendapat tempat dalam proses belajar mengajar bahasa Arab. Penelitian ini bertujuan untuk mendeskripsikan implementasi pembelajaran bahasa Arab melalui blended learning dan penggunaannya sebagai model alternatif belajar bahasa Arab di masa pandemi. Adapun metode yang digunakan yaitu mixed method di mana penelitian ini menggabungkan pendekatan kualitatif dan kuantitatif secara deskriptif yang memaparkan data yang diperoleh dari hasil wawancara, dokumentasi dan diperkuat dengan hasil survey terhadap proses pembelajaran bahasa Arab yang diperoleh dari para pengajar bahasa Arab. Hasil penelitian menunjukkan bahwa implementasi pembelajaran bahasa Arab melalui blended learning dengan menggunakan platform yang dipandang efektif sesuai dengan keadaan pengajar dan mahasiswa, serta penggunaan blended learning sebenarnya menjadi alternatif untuk melaksanakan pembelajaran tatap muka guna memberikan pemantauan pembiasaan berbahasa.
\end{abstract}

Kata Kunci: blended learning, bahasa Arab, pandemi 


\section{Arabi : Journal of Arabic Studies}

\section{Introduction}

Arabic language learning is essentially aimed at forming and building students who are competent with the knowledge of Arabic which is a means of understanding the content of Qur'an and Hadith. Language learning requires language habituation that is monitored in every learning process in the classroom. In the midst of the Covid-19 pandemic that hit the world, it requires all elements to study and work at home. This certainly has an effect on the continuity of Arabic education and learning which requires daily language habituation.

In carrying out the teaching and learning process during a pandemic, mastery of technology that is relevant to today's demands is required. The use of the right platform will have an impact on solving the problem of Arabic language learning. Educators' unpreparedness in presenting material through blended learning will determine the achievement of the expected goals.

Learning experiences should be provided to get adequate results with the participation of all groups to build an Arabic language environment that facilitates the accomplishment of the objectives of Arabic language learning. Even though learning is carried out through blended learning, the habituation of language skills must still be done by listening to listening material and responding to questions. Iskandarwassid (2009: 229) reveals that many of the listeners we meet are less skilled in everyday language, both mother tongue and second language, most adults spend time in communication activities, due to lack of focus attention, egocentrism, or memory nature through brief hearing.

Organizing an effective learning process with the use of the right platform will accelerate the mastery of Arabic language carried out interactively between teachers and students in a language environment. However, problems often arise, especially the lack of readiness of educators in carrying out blended learning so that the learning pattern is mostly carried out with assignments and similarities in the presentation pattern of the material that is still offline. This has an impact on the presentation of less well-prepared material and the use of unsuitable platforms for learning objectives.

Teachers' literate in technology is essential in the pedagogical practices. Educators' readiness to teach during this pandemic also brings demands to learn to use the available platforms, therefore, it is necessary to formulate how language habituation patterns can still be implemented through blended learning.

Blended learning in the modern era is a certainty that must be carried out considering situations where face to face communication is not possible. Thus, mastery of the resulting technology is a natural thing. The role of information media as an intermediary for achieving educational goals is a learning need that demands awareness and policies leading to the existence of the value of learning itself. Basically, the blended learning model combines face-to-face with modern technology and is seen as effective for all parties with careful preparation. With the blended learning model, learning takes place more meaningfully because the learning material has been designed in such a way that it can be easily understood by students (Hayati, 2018: 12).

Based on this problem, the implementation of blended learning needs to be done for the effectiveness of Arabic language learning. In the meantime, the importance of habituating Arabic language requires mastery of technology that can be applied in carrying out learning tasks that are intertwined with communication between educators, students and all groups in increasing mastery of Arabic language learning. Therefore, the aim of this study was to describe implementation of Arabic teaching through blended learning and using blended learning as an alternative model to Arabic language learning in the pandemic era.

Previous research has discussed a variety of this theme as carried out by Albantani (2019) entitled Social Media as Alternative Media for Arabic Teaching in the Digital Era, Ritonga (2016) entitled Arabic language learning Language Based on Information and Communication Technology in Padang, Iswanto (2017) entitled Arabic language learning with the Utilization of Technology, Hayati (2018) entitled Learning Management through Blanded Learning in 
Improving the Receptive Skills of Students at Islamic Boarding Schools and Dziuban (2004) entitled Blended Learning in Education Center for Applied Research.

However, the above mentioned studies only described alternative choices of media use models limited to innovation to provide new experiences. However, the lack of this study has not been able to reach the pandemic period which is required to continuously carry out blended learning without any opportunities for face-to-face conduct. Therefore, this study intends to fill in the shortcomings of previous research which was certainly carried out during the pandemic by utilizing blended learning that is relevant to the optimization of Arabic language learning.

\section{Method}

This research uses a mixed method by combining qualitative and quantitative approaches by describing the data based on the real conditions and the quantity of lecturers about the Arabic language learning model at PKPBA at the State Islamic University of Maulana Malik Ibrahim Malang. Data were collected through survey or questionnaire distribution to 136 PKPBA lecturers, information about implementation of blended learning and online teaching description. Then interviews were conducted to 14 lecturers who presented certain platforms about the Arabic language learning process. Meanwhile, documentation was done through notes in the form of assignments given to students via reported lecturer journals.

The data has been taken from the documentation about implementation of online learning through the reported lecture journals, the interview about information of learning implementation and the distribution of questionnaires after carrying out learning via Google Form as part of the lecture report that illustrate the acquisition of information about what media is used and the mastery of the instructor of the media in transforming the material being taught. Data analysis in this study was a concept offered by Miles and Huberman which includes: data reduction by selecting which data suits the needs of the document review and questionnaire distribution, displaying data by presenting the results of tabulations and mapping that have been made both narrative, and verification and conclusions carried out by confirming the results of the research made.

\section{Result and Discussion \\ Implementation of Arabic Teaching through Blended Learning}

Education in the modern era is affected by a global situation where all elements contribute to filling real life with its characteristic virtual communication processes. This pattern of life is essentially more or less impacted on the style of interaction and lifestyle that is faster with the use of adequate facilities and allow for knowledge that can be accessed directly without being taken in the formal world as experienced by learners in the past. The world health situation in all fields including politics, economy, security, social and even education also has an impact on the process of interaction among all elements to do all things independently and carried out in their respective settlements. This also provides an understanding that all work and learning must be done from home which means readiness in presenting learning material must reflect distance education patterns.

Arabic language learning in PKPBA during the pandemic was carried out boldly by all lecturers and new students in semesters 1 and 2 who were required to follow it for one year with the composition of male and female during the learning process. There are 136 active lecturers consisting of permanent and non-permanent lecturers with a composition of $55 \%$ female and $45 \%$ male who carry out blended learning.

Blended learning model as an effort to increase learning independence, the role of tutors based on theoretical and empirical studies in learning activities functions: (1) Growing students' awareness as learners and their importance to increase independence in learning; (2) Helping students as learners to be able to develop their potential, according to their talents and interests; 


\section{Arabi : Journal of Arabic Studies}

(3) Increase students' awareness of the importance of quality themselves efficiently in order to achieve achievements (Sutrisna, 2016: 166). Blended Learning has been popular in language learning and teaching methodology due to the fact that this digital era enables both students and teachers to access online sources easily (Isti' anah, 2017: 17)

Today's learning is done through electronic media or the internet, allowing students to access it anywhere and anytime. With the use of e-learning, it is expected to be able to improve student learning outcomes both to function as a supplement (supplement), complement (complement), as well as substitute (substitute) for conventional learning as said by Siahaan (Darmawan, 2014: 29). And there are a number of ways of judging the effectiveness of online and classroom teaching practices, one of the most common is measuring student learning (Jeffrey, 2014: 124)

Based on the results of the distribution of questionnaires, it was found that most of the instructors were not ready to apply blended learning because of the learning models that had been more dominant in the delivery of material through face-to-face in the classroom, so as to impact what models were used to provide understanding to students. This resulted in patterns of interaction between lecturers and students experiencing significant obstacles. The following are the results of a survey conducted for Arabic language lecturers who carry out online learning using various applications that lead to blended learning:

Table 1. Media Used by Lecturers in Arabic language learning Online

\begin{tabular}{ccc}
\hline Learning Application Media & Lecturers Quantity & Percentage \\
\hline Whatsapp Group & 84 & $62 \%$ \\
\hline Google Classroom & 23 & $17 \%$ \\
\hline Zoom Cloud Meet & 12 & $9 \%$ \\
\hline Google Meet & 3 & $2 \%$ \\
\hline Google Hangout & 3 & $2 \%$ \\
\hline Jitsi Meet & 1 & $1 \%$ \\
\hline Other Media & 10 & $7 \%$ \\
\hline
\end{tabular}

The table above shows that the application media that is more widely used by Arabic lecturers at PKPBA of UIN Maulana Malik Ibrahim Malang is the use of the Whats App Group to carry out blended learning in Arabic courses. This is due to the fact that lecturers are not ready in presenting material and interacting optimally with face-to-face and implementation of students' Arabic development, so that the use of chat, video calls, voice votes and document sharing is seen as reaching all of Maharah Lughawiyyah.

In addition, the use of Google Classroom also presents assignment material with several commentary or chat facilities which are actually easily accessible by both parties in carrying out Arabic language learning. This percentage is essentially in tandem with the willingness of lecturers and students who are constrained by the data plan and the strength of the signal which certainly helps encourage the smooth teaching and learning process. Meanwhile, other media have fairly good percentages where there are Facebook and YouTube media that provide variations in Arabic language learning. Expertise in managing Arabic language learning has a significant impact in providing valuable experience for students. Based on the results of the distribution of questionnaires to teachers, it was found that the learning model based on blended learning in general uses many applications as follows:

\section{WhatsApp Group Application}

WhatsApp application is an application that has been rife among the people of the world and even Indonesia where improvements have been made over time. This application is able to replace the role of the telephone as a means of direct audio communication and SMS as written communication that had experienced a trend in its time.

WhatsApp application is used for communication activities that can send text, audio and video messages that are utilized via the internet through android, smartphone and other facilities.

Vol. 5 No. 2 | $120-129$

Copyright (C) 2020 | ARABI | p-ISSN 2548-6616 | e-ISSN 2548-6624 
This application also offers the facility to communicate both personally and in groups through voice note and video call features, this will provide options and convenience in achieving the desired needs. In addition to online communication, this application is also equipped with file sending facilities, exchanging photos, videos and audio recorders (Hadi, 2016: 7). The forms of implementing Arabic language learning through WhatsApp are as follows:
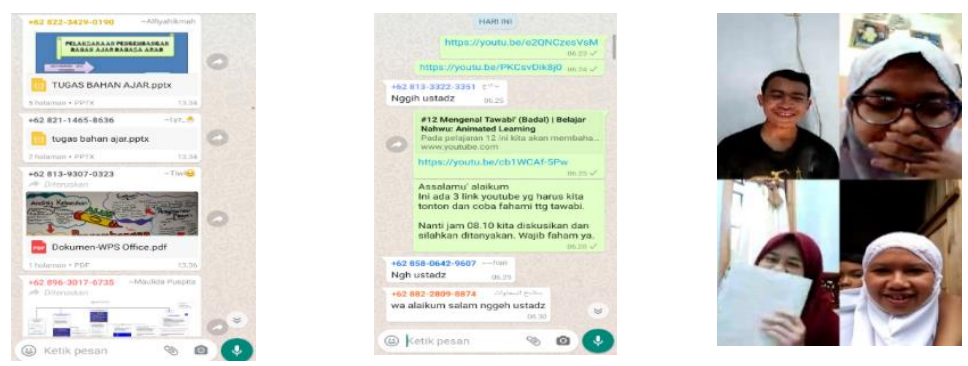

Picture 1. Teaching Arabic Through WhatsApp Group

Using the WhatsApp media in Arabic language learning can be done dynamically without limiting time, readiness to collect tasks or carry out all practical activities that can be sent in this application. As the picture above, the communication activities both via video calls and chat, will provide an interesting learning experience of course also must be balanced with appropriate learning techniques.

One menu that is often used in the process of Arabic language learning is a chat procedure that can be done either through private WA or group is limited to small groups. This group chat procedure is useful for conducting blended learning while still holding face-to-face but done remotely. The group can be used for both hiwar and istima practices, which between group members can directly interact and respond quickly (Sa'diyah, 2019: 159-160).

In using the WA application, teachers have at least 4 important roles in carrying out Arabic language learning tasks, including: 1) as an educational tool where teachers can give moral messages in each of their learning, 2) as an evaluation tool where teachers can provide responses to each task collected, 3) information connecting facilities, and 4) consultation service facilities (Makarima, 2019: 4-7).

WhatsApp as a modern communication media always offers new features and facilities that make users able to communicate in writing through chat, as well as audio visual in the form of video calls that participate in providing comfort in communicating. More than that, this application has a feature that is able to share messages in the form of photos, videos or any file to facilitate the delivery of more integrated information.

Based on the results of the questionnaire as explained earlier, it was stated that the WA application was most in demand by students because it was easily accessed without having to install other applications that actually existed in every smartphone they owned, the use of affordable quota and could be followed by all students without fear of the signal conditions not good (Hilmi, 2020). This situation is of course also supported by the menu owned by the application in facilitating and making greater use of all forms of communication and maximum interaction. Therefore, the use of this application is very effective for Arabic language learning that is sweeping the world of education in particular.

\section{Zoom Cloud Meet Application}

Zoom Cloud Meet application is an application that presents online face-to-face meetings based on meetings conducted by several people or many people with a host who will be an admin in managing the running of a meeting. This application is experiencing a rapid rise at this time where an atmosphere of mourning emerged of the Covid-19 outbreak which made all groups have to hold meetings after meetings online to continue carrying out daily activities. Wiranda (2019) in Herliandry (2020: 68) said that face-to-face discussion and transfer of knowledge like meeting 


\section{Arabi : Journal of Arabic Studies}

through a variety of video teleconferencing platforms are widely available free of charge such as zoom and Google Meet. This platform makes educators and students to meet and interact virtually with instant messaging facilities and presentation activities.

The process of Arabic language learning using the Zoom Cloud Meet platform is seen as being able to provide all the facilities needed in the learning process in the classroom, where the presentation process and forms of direct interaction can be implemented through blended learning, and the form of this platform display as follows:

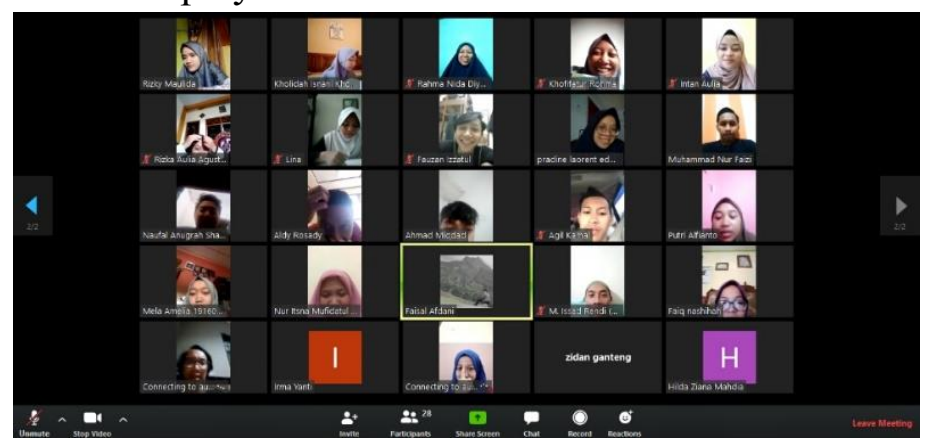

Picture 2. Teaching Arabic Through Zoom Cloud Meet

Zoom Cloud Meet has features for face-to-face-to-face meetings and is able to communicate more than WhatsApp which is only limited to 4-8 people if done in a group. This application is also able to detect the level of participation of its members and of course if done in the Arabic language learning process that can be monitored the participation of participants in each meeting. But unfortunately, this application often gets complaints where meeting participants often leave from the meeting because it turns out the operation requires a strong signal and sufficient internet quota strength and sometimes difficult to join or join in a meeting.

\section{Google Classroom Application}

The Google Classroom application is an application that presents several features of presentation of material and assignments accompanied by quiz columns that will complement learning in the network. Presentation of material presented in this application is more directing how to present material both in audio and visual form that can be accessed by students about Arabic material. Assignments and assessments in this application can be given directly by the instructor through the scoring that has been prepared.

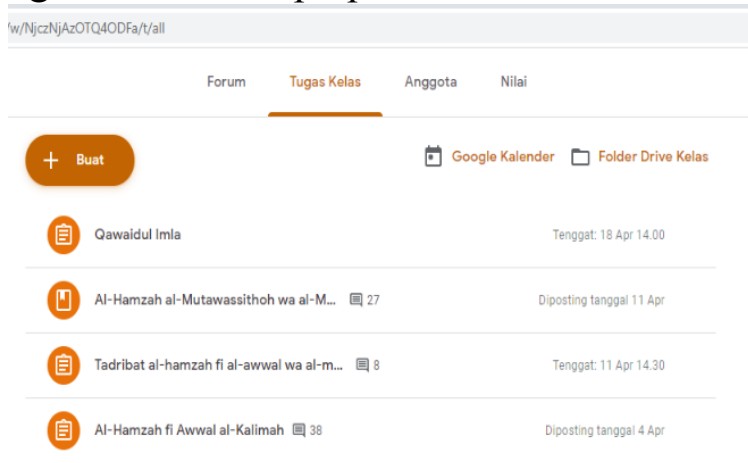

Picture 3. Teaching Arabic Through Google Classroom

Teaching Arabic through Google Classroom, teachers can see all the activities of students well by tracking each task that is collected so that it can be tracked to a predetermined time limit. Thus it can be seen who has done it and who has not given the value available in it (Shampa, 2016: 12-18). All of this is essentially an application prepared for learning at an educational level that uses cyberspace so that no longer used lectures, but the form of a brief explanation followed by assignments that can be given an assessment at each end of learning (Kusuma, 2019: 72) 
But in teaching Arabic using Google Classroom is seen as less than the maximum for faceto-face process where it only contains chat or conversation through writing as a medium to ask questions and provide answers. The video call or teleconference process cannot be done through this media so the learning is monotonous. Meanwhile, the advantage of this application lies in the menu to conduct evaluations by assigning assignments, examinations and grading learning outcomes directly which can store all records of the examination.

\section{Google Meet Application}

The Google Meet application is an application used in the distance learning process and can be blended learning in the form of virtual face-to-face learning. Google Meet actually belongs to Google which is affiliated with Gmail as a Login to bring together users. Unlike Zoom which has a limited duration if you want it free, Google Meet can be run for free without time limit and only rely on quotas only. This application also has similarities with Zoom that can display the presentation menu of the material to be delivered and the importance of the admin as a host to accept participants who want to Join in this application.

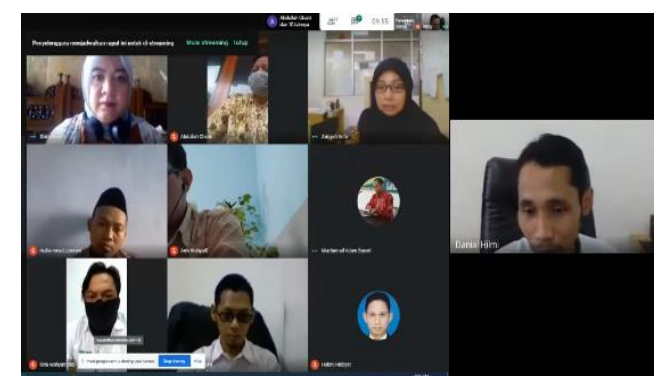

Picture 4. Teaching Arabic Through Google Meet

However, in using this application, there are several obstacles that are sometimes experienced including the ease of incoming noise so that it interferes with Arabic language learning activities, and for some people there is difficulty accessing, especially if there are already many participants while the admin is in a bad signal situation, this is because only one host and cannot be moved, while Zoom can be given a co-host that will back up if one of the admins experiences an obstacle.

\section{Google Hangout and Jitsi Meet Application}

The Google Hangout application is one of the applications used in online learning that can be done by blended learning with virtual face-to-face interaction with the ability to actively check student participation. Like the Zoom Cloud Meet and Google Meet applications, this application also has features that can be utilized by all people both for learning and for meeting activities. Online learning models have different types, those are synchronous learning and asynchronous learning. Synchronous Learning was a learning process carried out by lecturers and learners at the same time to enable direct interaction in the learning process either through the internet or intranet (Raharjo, 2020: 57). But the weakness of this application is the limited number of users who can join in it so it cannot accommodate large numbers or combined classes. Similarly, the previous application requires a strong signal that is stable for the learning process that runs well with the optimization of available features.

While Jitsi Meet application is an application that is present in the middle of the Covid-19 pandemic by presenting learning that can be accessed face-to-face between teachers and students in one view. Like the Zoom Cloud Meet application, this media can also do audio visual communication that is ready to compete in the process of teaching and Arabic language learning. 


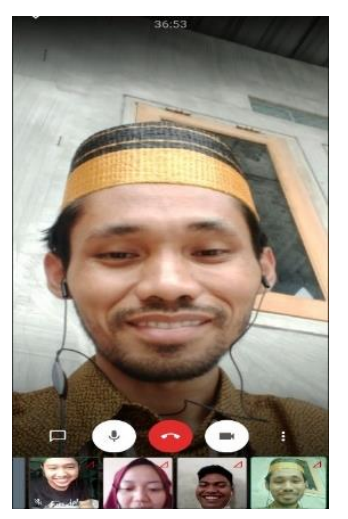

Picture 5. Teaching Arabic through Jitsi Meet

But this application also has a weakness where the sound that comes from outside can enter without a filter so that it often interferes with the learning process. Moreover, this media is considered safer than Zoom Cloud Meet because there is no obligation to sign out or register in advance which certainly requires an account creation as many are found in other applications.

\section{YouTube and Facebook Application}

YouTube application is a familiar application for all people, both for adults, teenagers and children, which presents various video shows that can be accessed easily in the search menu available. Considering there is a YouTuber profession that has the drive to upload videos, there are always new channels at any given moment. Today, many educational videos are found that provide educational shows both to help the process of understanding concepts and to carry out practical and simple language practices. In the meantime, video conversations in Arabic from domestic and abroad as well as various news programs in Arabic, also offer modern media that can be reached either independently or in groups.

Arabic teachers can also take the advantage of YouTube in improving students' motivation and interest in learning, in fact improving their understanding in Arabic language learning. Arabic teachers are able to create channels to upload many videos of vlog related to the Arabic teaching. They do not need much money; they only need phone cell with the camera to record video and the internet data plan to upload the video to YouTube channel (Albantani, 2019: 152). The forms of Arabic language learning by using the YouTube application are as follows:



Picture 6. Teaching Arabic Through Youtube

Unfortunately, this application only invites students to be passive to watch and listen to videos that have been prepared or browsed in advance by the instructor. However, it can still be commented on each show and interaction takes place alternately by leaving a comment on the video that has been done. This application, if designed well with variations in the assignment of tasks in the form of speaking skills through Vlogs or recording of speaking practices, will provide good benefits in addition to providing comments on what has been uploaded. 
For full and complete learning carried out continuously, then this application cannot be done because it is needed when there is face to face done by utilizing other application media that provide mutual benefits and efforts to achieve targets can be done optimally by prioritizing the habituation process that is the thing major in language activities.

Regarding Youtube, Facebook is an application that is actually familiar with social media users, but only a few using it because of the virtual interaction facilities that are not yet available except for chatting that is done in stages. But now, the latest features have been equipped with Facebook group facilities and live video that can be used to display learning activities by utilizing a webcam or smartphone camera to provide adequate means of interaction.

Arabic teachers can optimally use Facebook in their pedagogies. This social media has the feature of group so that it can collect students' account in one group. The Arabic teaching in group of Facebook can be started when the teachers share materials of Arabic language learning, for example isim, fi'il, and harf. After that, students are given task individually to give example in the column of comment one by one of the isim, fi'il, and harf freely but with the rule that they cannot give the same comment as the other has given. If there is same comment, teacher will warn the students to change it. The comments are likely become formative assessment in the teaching (Albantani, 2019: 154).

However, this application has constraints when applied in the process of Arabic language teaching and learning, namely the large number of menus displayed will result in the concentration of students becoming unfocused and the difficulty of monitoring their active participation in the teaching and learning process. Therefore, teachers need to pay attention to what competencies are appropriate to be developed through this application so that the desired objectives can be achieved.

\section{Blended Learning as an Alternative Model to Arabic language learning}

The effectiveness of Arabic language learning in a variety of situations, it is necessary to make a creative and innovative effort through the use of media. This is because it will provide a strong impetus and can increase students' motivation in mastering Arabic concepts and practices. Besides there are various media that are very supportive and relevant in an effort to provide an explanation directly conducted by the instructor optimally (Hilmi, 2017: 132). Holistic language experience is the soul of this theory in the language classes, which depends on contentorientedness, authentic and complex learning environment (Aljohani, 2017).

The presence of technology-based learning support facilities does not necessarily become a solution to a pandemic situation that requires learning through blended learning, it requires expertise to integrate pedagogies and reliability in utilizing available technology. If these two things cannot be done, it is not impossible that the problem will not be handled or even worse than the current process. Harahap (2019) said that the use of technology such as the internet in improving the education achievement has increased rapidly.

One of the factors that has not yet created Arabic language skills among learners is because the models and strategies used by educators so far are not in accordance with the soul and character of students. Students at the Islamic Junior High School level in general are already familiar with computers. Their familiarity with various information and communication technologies requires the creativity of educators to carry out the learning process in accordance with their souls and needs (Ritonga, 2016: 2). The teachers, syllabus and course designers have to put efforts to design and develop attractive and innovative course materials (Aladdin, 2007).

The appropriateness of the learning process with the conditions of the students is indeed needed to generate motivation to learn. In the meantime, the continuity of the transformation of science will not run optimally if it is not supported by the readiness of students to follow the learning process. Therefore, the creativity of language instructors is required, especially in 


\section{Arabi : Journal of Arabic Studies}

managing learning in a network that actually takes place today amidst the Covid-19 pandemic and requires all parties to carry out learning in their homes.

The learning model is constantly developing along with the times that is happening both through the discipline of the fields of language, education, and other fields which of course also experience development. Moreover, the results of the study, especially in the field of language teaching also contribute significantly in shaping and developing a new method or learning model (Faridi, 2009: 59).

The new learning model as much as possible is done by looking at the latest developments and in line with the direction of learning of students in capturing material that is easier and more directed. The readiness of teachers in mastering information technology and skills in managing learning is seen as the main thing in producing the quality of learning as desired. Using learning with a blended learning model can increase student learning time. Students can improve their subject matter mastery by repeating learning material several times, practicing questions both independently and in groups (Eklund, 2003).

This subsection focuses on the new approaches to teaching that overcome barriers of distance, time and age. These new approaches provide broad opportunities for learning beyond the classroom, and also for more varied and deeper learning. These opportunities (a) include online interaction between the learner and their teacher or peers, and (b) show that e-learning is no longer associated just with distance learning, but is also about using relevant technologies. Thus, elearning is an important part of a suite of approaches that aim at providing the best and most appropriate ways of supporting learners' engagement and achievement (Lora, 2016: 4).

In Arabic language pedagogy, it is necessary to have a shared understanding related to the concept of learning itself by paying attention to what lies behind learning in the form of utilizing online interactions between teachers and students. Interactions that remain directly intertwined can also be held through information technology through distance learning so that the urgent side of learning can still be carried out despite the distance between all class members. Online learning requires more independent learners to fulfill the desired skills. Bloomsburg (2006) defines that elearning is a means of education that includes self-motivation, communication, efficiency, and technology (Iswanto, 2017).

Smartphone or android is not only used as a means of communication, but nowadays it can also functions as an educational or learning media for distance learning. It can also be done by collaborative learning by utilizing applications available on the play store where all students can take part in face-to-face learning distance or referred to as blended learning. Learning with this media makes it possible to interact actively with the provision of feedback to get full and effective knowledge (Sulhadi, 2020: 40). In such cases, they mostly find odd moments and time left between their other multiple activities throughout the day. In other words, they learn when and wherever they can (for instance, at home, at university, or on public transport). This is what the term ubiquitous learning means (Peng, 2009).

The most ideal media in the Covid-19 pandemic, where class members did not face each other physically, namely the application media by utilizing their smartphones, so that the tendency of students to love this media can be fulfilled through the use of appropriate applications. Besides that, blended learning invites all class members to make the learning process more productive in conducting language habituation by using various recommended media and assignments as an integrative form of enrichment in a teaching and learning process.

Chapelle (2001: 55) stated that there is a learning pattern that is done by using a computer with the obligation to meet the criteria adjusted to the characteristics of Computer-Assisted Language Learning (CALL). Therefore, to realize the learning process by using computers, the following criteria for computer-assisted language learning: 
Tabel 2. Criteria for Computer-Assisted Language Learning (CALL)

\begin{tabular}{ll}
\hline $\begin{array}{l}\text { Language } \\
\text { Learning } \\
\text { Potential }\end{array}$ & The degree of opportunity present for beneficial focus on form. \\
\hline Learner Fit & $\begin{array}{l}\text { The amount of opportunity for engagement with language under } \\
\text { appropriate conditions given learner characteristics. }\end{array}$ \\
\hline Meaning Focus & $\begin{array}{l}\text { The extent to which learner's attention is directed toward the meaning of } \\
\text { the language. }\end{array}$ \\
\hline Authenticity & $\begin{array}{l}\text { The degree of correspondence between the computer-assisted language } \\
\text { learning activity and target language activities of interest to learners out } \\
\text { of the classroom. }\end{array}$ \\
\hline Positive Impact & $\begin{array}{l}\text { The positive effects of the computer-assisted language learning activity } \\
\text { on those who participate in it. }\end{array}$ \\
\hline Practiciality & $\begin{array}{l}\text { The adequacy of resources to support the use of the computer-assisted } \\
\text { language learning activity. }\end{array}$ \\
\hline
\end{tabular}

Based on the above table, it can be concluded that learning a foreign language by using computer media with all applications like a smartphone is a concern to be fulfilled to optimize the process of Arabic language learning. In the meantime, the potential for Arabic language learning must be possessed first so that the motivation that comes from all components is first prepared before the implementation of computer-aided learning.

The condition of the learner needs to be a concern to form a culture of awareness of the acquisition of a strong language with a focus on activities that build the language motivation embedded in the learner. Besides that, it is necessary to have the authentic learning that prioritizes the local context and real implications when applying application-based learning with a practical learning process by prioritizing the practice of communicating verbally and in writing through media that has been prepared in online learning.

The adoption and utilization of educational technology in the developing countries face many difficulties in the educational system and it does not always lead directly proportional increases in student learning outcomes. Therefore, it is very important to investigate and understand the critical success factors in order to optimize student outcomes (Kashada, et. al 2018: Buska, 2020). The achievement of Arabic language proficiency depends on the teachers' skill in processing learning by utilizing media relevant to the interests of students.

\section{Conclusion}

Arabic language learning during the Covid-19 pandemic has changed the structure of life and patterns of interaction that are evident in the teaching and learning process. This also impacts on the continuity of learning in the classroom which requires a change to become a virtual-based learner. One of Arabic language learning models to meet this need is the use of a blended learning model that can be done face-to-face but integrates with distance learning that can be done from home as the government's message to stay at home. Nowadays, the demand of ICT in Arabic language learning rises rapidly, especially during a pandemic which demands the use of technology to realize blended learning. Therefore, Arabic language learning at PKPBA utilizes the available online platform by bringing together the available platforms by maximizing face-to-face learning with distance. The use of blended learning is a necessity and an alternative model that can make the pandemic situation effective in the world. An alternative model in implementing learning will be useful in addition to presenting material online as well as inviting students to further develop themselves individually. Therefore, blended learning becomes an alternative model which is very important to meet the expectations of Arabic language learning.[] 
Arabi : Journal of Arabic Studies

\section{References}

Aladdin, A. 2016. "A Needs Analysis for the Course Materials Design of the Arabic Language Course", International Journal of Social Science and Humanity, Vol. 6, No. 6.

Albantani, A. M. 2019. "Social Media as Alternative Media for Arabic Teaching in Digital Era", Alsinatuna: Journal of Arabic Linguistics and Education, Vol. 4, No. 2.

Aljohani, M. 2017. "Principles of Constructivism in Foreign Language Teaching", Journal of Literature and Art Studies, Vol. 7, No. 1.

Buska, W. et al. 2020. "The Management of Language Laboratory in Improving Students Arabic Competence", Arabi: Journal of Arabic Studies, Vol. 5 No. 1.

Chapelle, C. 2011. Computer Applications in Second Language Acquisition. Cambridge: Cambridge University Press.

Darmawan, D. 2014. Pengembangan E-Learning Teori dan Desain. Bandung: PT. Remaja Rosdakarya.

Eklund, L. 2013. E-learning Emerging Issues and Key Trends. Australia: Flexible Learning Framework.

Faridi, A. 2009. "Inovasi Pembelajaran Bahasa Inggris Berbasis ICT dalam Rangka Meningkatkan Mutu Pendidikan”, Jurnal Lembaran Ilmu Kependidikan, Vol. 38, No. 1.

Hadi, B. 2016. "Pemanfaatan Aplikasi Whatsapp Pada Pembelajaran Berbasis Blended Learning di SMKN 1 Sragen", Article presented at academic forum at SMKN 1 Sragen.

Harahap, F. et al. 2019. "The Effect of Blended Learning on Student's Learning Achievement and Science Process Skills in Plant Tissue Culture Course", International Journal of Instruction, Vol. 12, No. 1.

Hayati, N. \& Wijaya, M. 2018. "Pengelolaan Pembelajaran Melalui Blanded Learning Dalam Meningkatkan Receptive Skill Peserta Didik di Pondok Pesantren", Palapa: Jurnal Studi Keislaman dan Ilmu Pendidikan, Vol. 6, No. 2.

Herliandry, L. D. et al. 2020. "Pembelajaran pada Masa Pandemi Covid-19”, Jurnal Teknologi Pendidikan, Vol. 22, No. 1.

Hilmi, D. 2020. "Peluang dan Tantangan Pembelajaran Bahasa Asing di Masa Pandemi Covid-19”, Article presented at Language Forum Webinar in UIN Maulana Malik Ibrahim Malang.

Hilmi, D. 2017. “Sistem Pembelajaran al-Qawa'id al-Sharfiyah di Indonesia”, Tarbiyatuna: Jurnal Pendidikan Ilmiah, Vol. 2, No. 1.

Iskandarwassid. 2009. Strategi Pembelajaran Bahasa. Bandung: PT Remaja Rosdakarya.

Istu'anah, Arina. 2017. "The Effect of Blended Learning to the Student's Achievement in Grammar Class", Indonesian Journal of English Education, Vol. 4, No. 1.

Iswanto, R. 2017. "Pembelajaran Bahasa Arab dengan Pemanfaatan Teknologi", Arabiyatuna: Jurnal Bahasa Arab, Vol. 1, No. 2.

Jeffrey, L.M. et al. 2014. "Blended Learning: How Teachers Balance the Blend of Online and Classroom Components”, Journal of Information Technology Education Research, Vol. 13.

Kashada, A. et al. 2018. "Analysis Approach to Identify Factors Influencing Digital Learning Technology Adoption and Utilization in Developing Countries", International Journal of Emerging Technologies in Learning (iJET), Vol. 13, No. 2. 
Kusuma, A. B. \& Astuti, W. 2019. “Analisis Penerapan Media Pembelajaran Bahasa Arab Berbasis Aplikasi Google Classroom”, Jurnal Lahjah Arabiyah, Vol. 1, No. 1.

Lora, A. P. et al (ed). 2016. Applying Information and Communication Technologies to Language Teaching and Research: an Overview On New Perspectives on Teaching and Working with Languages in The Digital Era. United Kingdom: The British Library.

Makarima, M. M. 2019. "Pemanfaatan Aplikasi Daring Media Sosial WhatsApp sebagai Media Pembelajaran Bahasa Arab Berbasis ICT”, Article published at https://www.academia.edu

Peng, H. et al. 2009. "Ubiquitous knowledge construction: mobile learning re-defined and a conceptual framework", Journal of Innovations in Education Technology, Vol. 46, No. 2.

Raharjo, D. H. et al. 2020. "Improving the Students' English Skills Through Online Activities in Moodle Platform", Langkawi: Journal of The Association for Arabic And English, Vol. 6, No. 1.

Ritonga, M. et al. 2016. "Pembelajaran Bahasa Arab Berbasis Teknologi Informasi dan Komunikasi di Kota Padang", Arabiyat: Jurnal Pendidikan Bahasa Arab dan Kebahasaaraban, Vol. 3, No. 1.

Sa'diyah, H. 2019. "Upaya Menumbuhkan Self-Confidence Berbicara Bahasa Arab Mahasiswa Melalui Grup Whatsapp", Jurnal al-Mi'yar, Vol. 2, No. 2.

Sulhadi, A. 2020. "Media Pembelajaran Bahasa Arab Berbasis Android dengan Menggunakan Aplikasi Arruz Untuk Penguasaan Nahwu di Jurusan Sastra Arab UIN Sunan Kalijaga Yogyakarta", El-Tsaqafah: Jurnal Jurusan PBA, Vol. 19, No. 1.

Sutisna, Anan. 2016. "Pengembangan Model Pembelajaran Blended Learning pada Pendidikan Kesetaraan Program Paket C dalam Meningkatkan Kemandirian Belajar", Jurnal Teknologi Pendidikan, Vol. 18, No. 3. 